\title{
流体の往復振動によって誘起される対流熱伝達*
}

\author{
小澤守*1, 瀧藤知 成*2, 河本 明*3
}

\section{Convective Heat Transfer Induced by Fluid Oscillation}

\author{
Mamoru OZAWA, Tomonari TAKIFUJI and Akira KAWAMOTO
}

\begin{abstract}
Numerical simulation was conducted on the heat transfer process in a two dimensional flow field imposed by a sinusoidal oscillation of fluid. When gravitational force was ignored, the heat transfer at the wall was similar to a forced flow turbulent heat transfer. On the other hand, under gravity, two modes of mixed convection heat transfer were observed depending on the thermal boundary conditions. For high viscosity fluids, the bifurcation of the flow pattern appeared, which was mainly determined by the oscillation amplitude.
\end{abstract}

Key Words: Heat Tranofer, Heat Transfer Enhancement, Mixed Convection, Oscillation, Iream Pipe, Numerical Simulation

\section{1. 緒言}

近年, Kurzweg ら(1)(2)によつて管内の液体に往復 振動を加えることにより液体の伝導伝熱を飛躍的に促 進する熱輸送機構としてドリームパイプが考案され た。が国に扔いてもその研究に触発され，著考

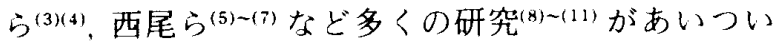
で行われた。

ドリームパイプの熱輸送の基本は往復振動によって 形成される壁面近傍の振動境界曾を媒介としたカスケ ード式のヒートポンピングによるものであり、Watsonによる物質の異常倣散 ${ }^{(12)}$ とのアナロジ一が成市 する(5).この上うな熱輸送管屿作動流体や挔幅, 周波 数の選択が適切であれはば銅の熱桩散率の数十倍から数 百倍の亳効熱抬散率を有寸るこ上になるが，高性能の 熱輸送デバイスを設計するためには熱輸送管の両端に 存在する吸熱あるいは放熱などの熱交換部での基本的 特性を把握することが必要不可久である。

この上うな熱交換部においては熱輸送管部と異な

* 原稿受付 1995 年 10 月18 11.

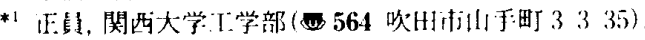

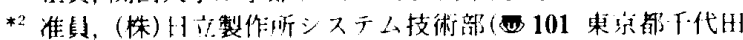

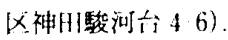

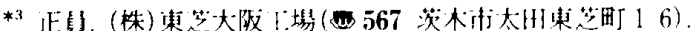

り、振動に上って誘起された強制対流的な流動方[局人 の熱輸送だけでなく側壁への熱移動を伴うことから， 現象的には管壁を通じての伝熱を伴う通常の強制対流 熱伝達の機構に近ー゙くことになる。このような振動場 の伝熱現象に閔しては，平均流に振動流を付加した Hyunらの一連の研究 ${ }^{(13)(14)}$, 振動によって誘起されるる 円柱周りの共存対流に着目した Kikuchi らの研究 ${ }^{(15)}$ など興味深い報告がなされているが、特にドリームパ イプに関するものとして Kavianyら(16)17)や稻㷊の研 究(10) がある程度で、流れの機構にまで言及したけ行 な解明が行われているとはいい難い状沅にある。

そこで本報では著者らが既報はで用いたドリー人 パイプの数㑬シミュレーションモデルをベースとし て，数储シミュレーションによって熱交換部の熱流動 場と伝熱の基本的な特性の把握を行い，またそこで発 生する共存刘流現象について検討した結果について報 告する.

\section{2. 数值シミュレーションモデ}

数值シミュレーションモデルは図1に示子ように左 有両側壁を等温壁とした二次元流路である。数做シミ

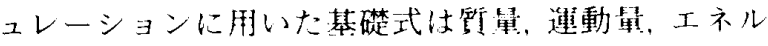
ギーの各保存式で，ブシネ近似を施した保存式を朋い 


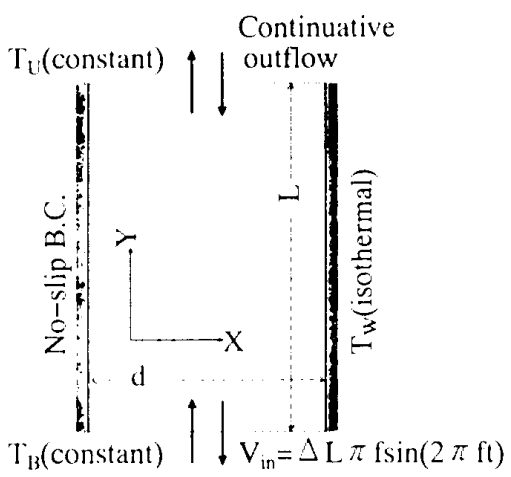

Fig. 1 Simulation model

ることとした。な打本報では温度差が大きくしかも作 動流体として水だけでなく筒ブラントル数流体である シリコンオイルについてもブシネ近似を用いたことに

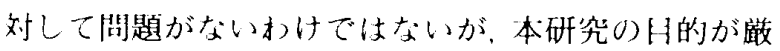
密公伀熱の相関式の誘導ではなく等性的な現象の把挂

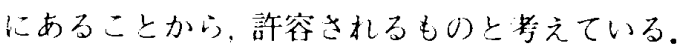

数值シミュレーション手法はHSMAC 法であり，

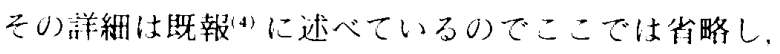

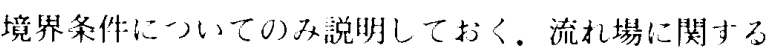
境界条件仕，（1）流路比鉛㨁に設置されているとす る。ただし熟伝達の基本的な特性在検佮寸るために和 カの加速度 $g=0 \mathrm{~m} / \mathrm{s}^{2}$ の場命についても計算した。

(2)合们出側壁は滑りなしとし、ト端での滩体の流 入速度 $V_{\text {in }}$ は

$$
V_{\text {in }}=\Delta L \pi f \sin (2 \pi f t)
$$

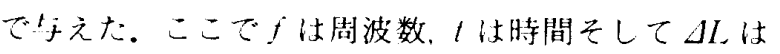

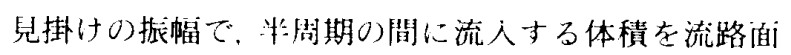
積と時間で除したものである。（3）端は主抽流人流 出条件在打いた。一方，温度場に関字る境界条件とし ては，(4)后布側壁り温度は一定温度 $T_{w}$ とし，また (5) 1:卜端加流人寸る湾体温度もそれぞれ一这温度 $T_{\because}, T_{B}$ とした。

本報でシととして川いた温度場の境界条件は次の２乇 ードである。

Mode A : $T_{l}=30^{\circ} \mathrm{C}, T_{B}=20^{\circ} \mathrm{C}, T_{w}=20^{\circ} \mathrm{C}$

Mode B : $T_{t}=20^{\circ} \mathrm{C}, T_{s}=30^{\circ} \mathrm{C}, T_{w}=30^{\circ} \mathrm{C}$

本モデルは咕防に設置されたドリームバイブト端の

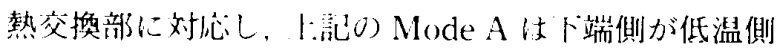
の場命，ModeB は下端側が战温側の場命上考えるこ とができる。

計算モデルの法は流路幅 $d=9 \mathrm{~mm}$, 流路長さ $L$, $=15 \mathrm{~mm}$ を中心として, アスベクト比 $d / L$ の影響に

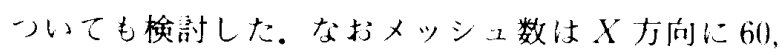
$Y f_{j}$ 们に $30(d / L=9 / 15$ では $\Delta X=0.15 \mathrm{~mm}, \Delta Y=$
$0.5 \mathrm{~mm})$ とした。振動周波数は $f=0.3 \sim 50 \mathrm{~Hz}$ ，また見 掛けの振幅は $\Delta L=1,3 \mathrm{~mm} 0) 2$ 種類について検討し た。シミュレーションに際しては流路內の初期流体温 度 $T$ in が低温側の温度 $\left(20^{\circ} \mathrm{C}\right)$ に等しく，また流体は静 此しているとして胡算を開始し，流机場の温度分布， 流速分布が・分に発達寸るまで計算を行った。

\section{3. 振動場における熱流動の基本的特性}

\section{$3 \cdot 1$ 速度分布と温度分布 温度分布が㤋発達} した後の流路内での空間的また時間的な流速分布，温 度分有について説明する。ただし自然刘流の影響につ いては 4 章に扔いて検郭するので，ここでは $g=0 \mathrm{~m} /$ $\mathrm{s}^{2}$ とし，作動流体を水とした場令を例にとって説明す 3.

网2上3には条件が ModeA の場命の流速の流路断 面内分佃( a ), 温度分佃 $\left(T-T_{\text {in }}\right)($ b ) , そして流路側

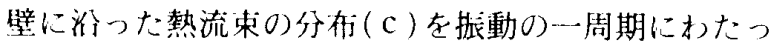
て示している。威2は $\Delta L=3 \mathrm{~mm}, f=10 \mathrm{~Hz}$ ○場令で あり，烟 3 は $\Delta L=3 \mathrm{~mm}, f=0.3 \mathrm{~Hz}$ の場命である。 そ して为2，3ともに温度分布上流速你布は流路の卜端 から0胡き $Y / L=0.583$ 在代表として示している。咸

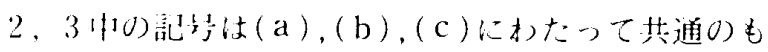

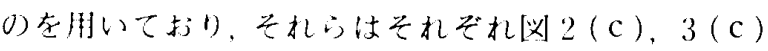
中に亦さ机ている。

威2（a）に示されている $f=10 \mathrm{~Hz}$ の場命について みると，流速你用は流路中央のバルク部分ではほほ一 足で, 挀動の位相によってほほ头行に移動している。

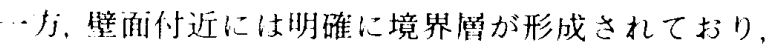
速度変動はバルク部分での举動と明らかに位相差が存 在吉る。バルク激分上明り上うな位相差が存在する振

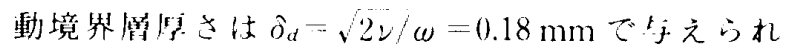

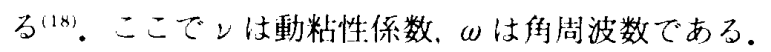
バルク部分に相刘的な速度变動の振幅は壁面か心の距 離 $X$ に対して $\exp \left(-X / \delta_{d}\right)$ に比例して小さくな

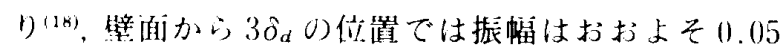

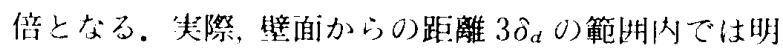
らかにバルク部分と速度が珙なり、こ机が速度分布か

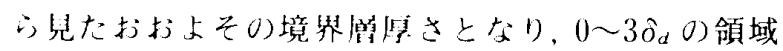
に打いて流速変動の位相差のために一倜期中心西る位 相で柾大值あるいは極小佰をもつのが特徵的である。

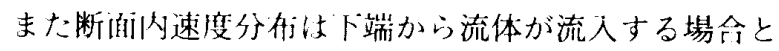
流计寸る場命で対称である。一方，図 3 (a)に示され ている $f=0.3 \mathrm{H} z 0)$ 場合には速度は壁面から流路中心 に们かのてなめらか江変化し，速度が顕著に異なる境

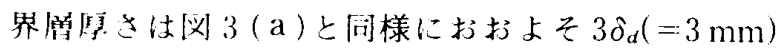
でけえら机る。交扮周波数が小さい場命には速度分用 


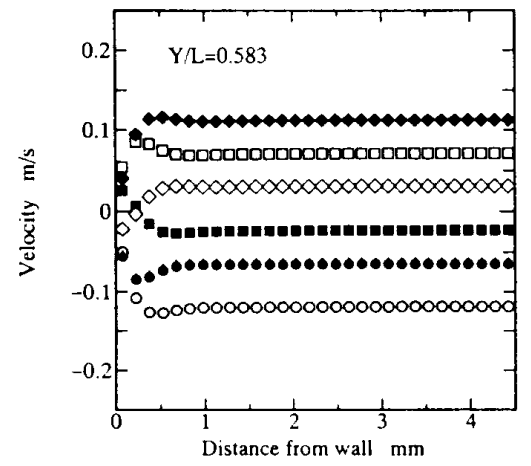

(a) Velocity distribution

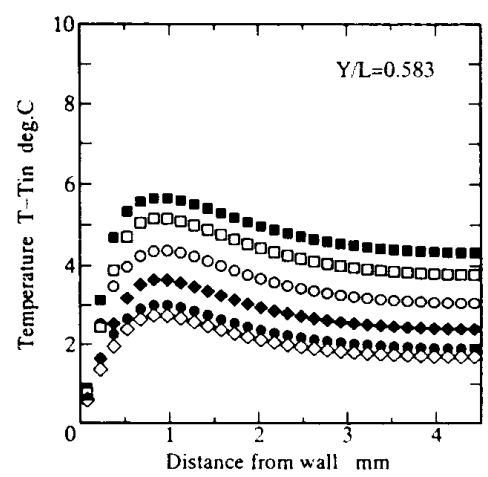

(b) Temperature distribution

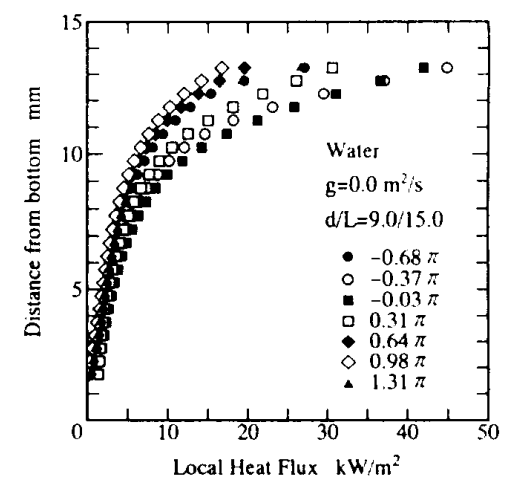

(c) Heat flux distribution

Fig. 2 Distribution of velocity, temperature and heat flux $\left[g=0 \mathrm{~m} / \mathrm{s}^{2}, f=10 \mathrm{~Hz}, \Delta L=3.0 \mathrm{~mm}\right.$, Mode A, see legend in $\left.(\mathrm{c})\right]$

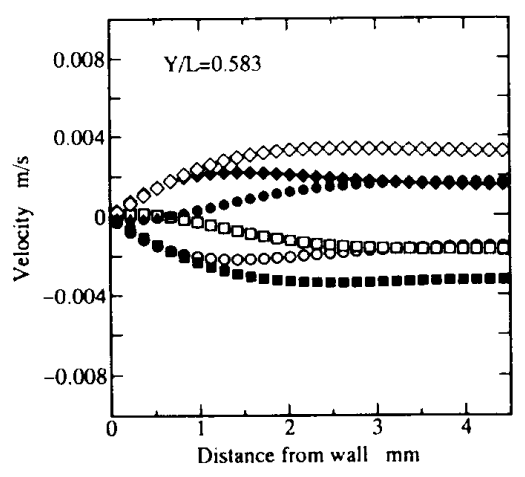

(a) Velocity distribution

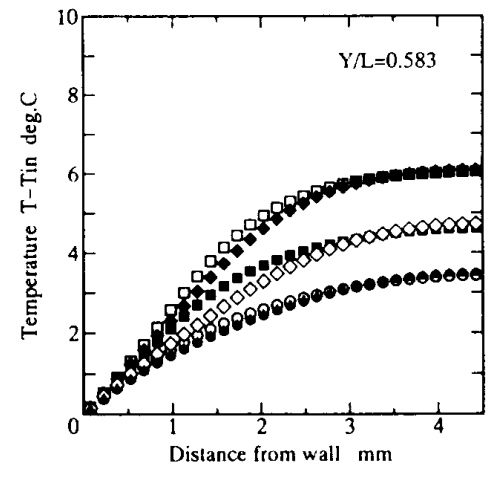

(b) Temperature distribution

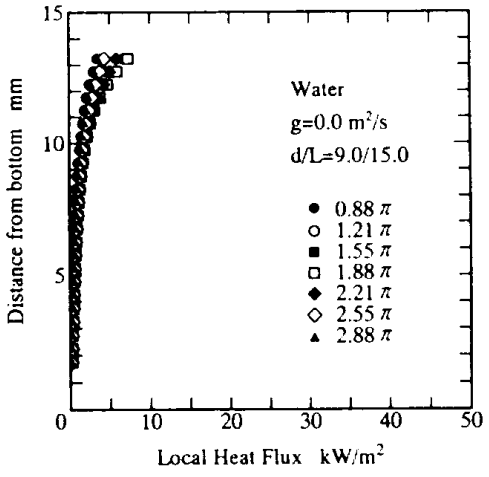

(c) Heat flux distribution

Fig. 3 Distribution of velocity, temperature and heat flux $\left[g=0 \mathrm{~m} / \mathrm{s}^{2}, f=0.3 \mathrm{~Hz}, \Delta L=3.0 \mathrm{~mm}\right.$, Mode A, see legend in (c)]

が平たんな部行は流路中央のごく狭い部分に限走され ている。

次に温度分布についてみると, $f=10 \mathrm{~Hz} \sigma$ 場合に は温度の最毛高い部分が扮拈上そ $4 \delta_{d}$ 付近にあり、こ の部分から壁通抢よびバルク部分に向かって温度が降 トしている。またバルク部分の温度分布は時間的にほ ほ半䘕に変動しており、温度変動の位相差は $4 \delta_{d}$ の部 分とバルク部分ではほとんどない。速度分有と命せて 考えると，流動方向の熱輸送は主として側壁加ら $4 \delta_{d}$ の簿州の部分を通じて行われ，バルク部分は熱輸送に はあまり奋与しない.・无， $f=0.3 \mathrm{~Hz}$ の場合には流速 変動に対忍して温度境界層厚さも厚く，また $f=10$ Hzの場命の上うな極大值は認められない。このよう な低周波数の場合には流動ち向の熱輸送にはバルク部 你が主体的な役割をはたしている。このような速度分 布や温度行布の特性はプラントル数が水よりも大きい シリコンオイルを作動流体とした場合にも諗められ， 例えば $10 \mathrm{cSt}$ の場合 $f=10 \mathrm{~Hz}$ では速度境界厤の目

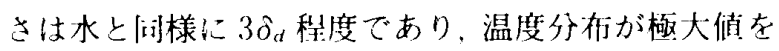

示す位置は水の場命よりも小さく $2 \delta_{d}$ 付近である。振 動場におけるこれら境界居厚さに関寸万特性は通常の

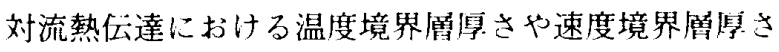
とプラントル数の関係と同様である。温度の境界条件 が Mode Bの場合には速度分相の変動は戍2（a），3 (a)と同じで，温度分为は为2（b），3（b)とは逆転 した形、つまり緃軸の温度を $10.0-\left(T-T_{\mathrm{in}}\right)$ の形に 值したものとなる。

本報に打けるお聿な対象である壁㓦に治つた熱流東 0分布が戍 2 (c)，3（c）に亦されている，上端温度 $T_{U}$ が側壁 $T_{W}$ や下端 $T_{B}$ に比バて高いため，上部で 熱流束が最も大きく、下部に向か一て小さくなる。文 た拢動 0 位相によって熱流束は大きく変化し，高温側 の流体が流入してきたときに大きな熱流束となり，逆 に低温側の流体が流入してきたときに熱流束は小さく なる、捇動周波数が低くなると熱流柬の倠もその変動 も小さくなる。な招 Mode B の場令には熱移動の才淌 が Mode A とは逆転するが，熱流束の行办とその変動 の絶対值は Mode Aでの結果と一致している。 


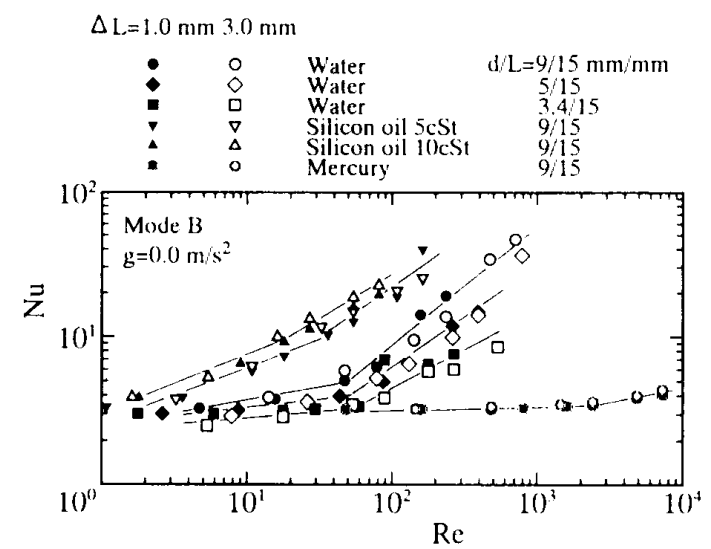

Fig. 4 Heat transfer at the wall $\left(g=0 \mathrm{~m} / \mathrm{s}^{\prime}\right)$

$3 \cdot 2$ 側壁での熱伝達特性次に強制刘流熱佉達 と间样な医法で側集に打ける熱位達率を算计し，強制 刘流熱位達との関連について検討してみる。部拈よ

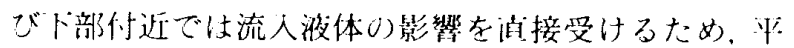
均熱流東訸を算出寸るに際しては，この影觜の少な

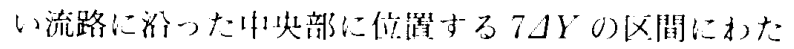

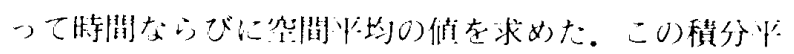
均同間は $d / L=9 / 150$ 場命には $7 \Delta Y=3.5 \mathrm{~mm}$ (下端

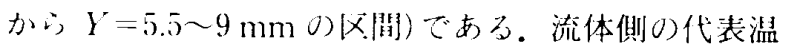

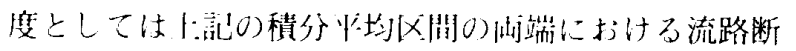

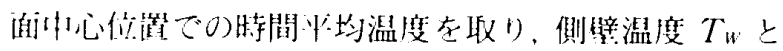

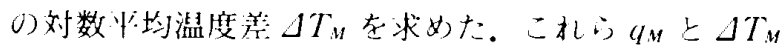

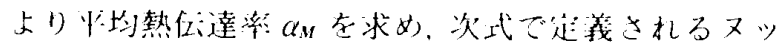
セルト数Nuと吅報(3)(4) 上问様な形の)レイノルズ数 Re 0閂係で表示けする。

$$
N u=\alpha_{w} d / \lambda, \quad R^{\prime}=2 d f \Delta L / \nu
$$

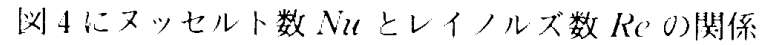
がホきれている。ここでホしたたは Mode Bのシミュ

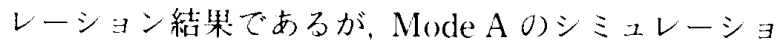
ン絬果と一致することを確䜑している。兴４中心はd $L=9 / 15$ で作業流体が水, $5 \mathrm{cSt}$ 抽よび $10 \mathrm{cSt}$ のシリ ロンオイル，水銀り条場令のシミュレーション結果が 小されている。妨水に一いてはd/L=5/15、3.4/15

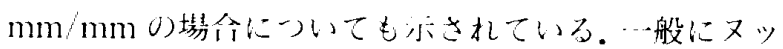
セルト数はレイノルズ数け增加とともに大きくなり， そのこう配はレイノルズ数が小さい領域で小さく，水 0場令には打打よ $R e=50$ を境として大きくなって

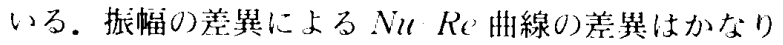
小さく、式(2)ひ起義が有效であることをホしてい る。[间様な傾间はシリコンオイルや水銀に刘しても， また流路幅が基なる場命に毛諗められる。NURe曲 線けこう配が变化寸る浢移レイノルズ数は水銀では

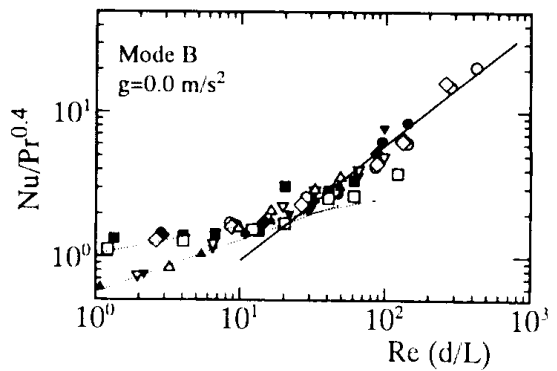

Fig. 5 Heat transfer correlation $\left(g=0 \mathrm{~m} / \mathrm{s}^{2}\right.$, see legend in Fig. 4$)$

2000 , シリコンオイルでは10〜30 程度で, プント 儿数Prが大きくなるに従い遷移点はレイノルズ数の) 小さいほうに移動する。

ここで刘象としている系では往復拢動による強制対 流的な流動力们への熱移動と，流路各所での側壁力向 からの熱移動が间時に䘕れ机ている。低レイノルズ数 域では閖波数增打に伴う流体移動が最も顕著であるバ ルク部尔が熱輸送の主体であることから流動厅向には $f^{2}$ に比例して熱移動が促進される(5)が，网3(b)から も明らかなように，側售付近のこう配が小さく，また 䦭波数增加に伴うこの部分での温度こう配の変化も小

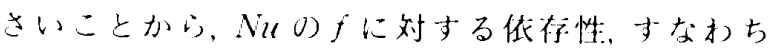

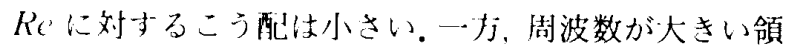
域では流動力向への熱移動は側集近浐の境界屏によっ

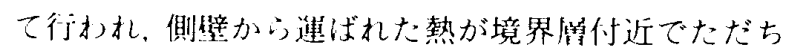

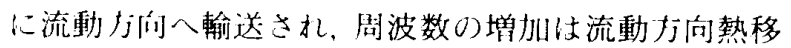
動にもまた側壁力们熱移動にも问程度の促進効果とな つていると琶わ机る。

ヌッセルト数の值はブラントル数が大きくなると大 きくなり，特に问レイノルズ数域の Nu-Re閶係はほ ほ中行に移動している。このヌッセルト数Nルのプラ ントル数 Rrに対する依存性は扔拈よそNu〜Pr. と表される。ただし水銀の場命は熱位導率が極めて大 きいため，振動䧓波数に対してヌッセルト数の変化は ごくもずかしか琹められない。また流路幅 $d 0$ 異なる 場令け結果を比較すると，槀レイノルズ数域において 流路幅が小さくなるとNu倠は小さくなる傾问があ

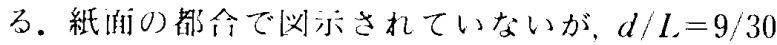
$\mathrm{mm} / \mathrm{mm} 0$ 場命にも问様な $N u$ の低下が諗められる ことから、ヌッセルト数はd/LO関数でもあること がわかる。このことは強制対流熱伝達とのアナロジー で努えれば、熱流動場が発達域であることに対仝寸 文.

これらブラントル数 $\mathrm{Pr}$ とd/LO影慗を考慮して

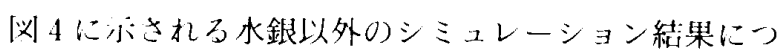


いて $\mathrm{Nu} / \mathrm{Pr}^{0.4}$ と $\mathrm{Re} \times(\mathrm{d} / \mathrm{L})$ の関係でプロットしな おした結果が図 5 に示されている(記号は四4と其 通).高レイノルズ数域の各シミュレーション結果は幾 何学的才法や流体にかかわらずほぼ1本の直線の周り に分布している。一方，低レイノルズ数域ではシリコ ンオイルの 2 種類のシミュレーション結果は 1 本の直 線で表されるものの水に対する值線とは一致しない. この領域では熱伝達特性を相関するのに Prと $\operatorname{Re}(d / L)$ だけでは不十分であることになる.

管内強制対流乱流熱伝達は一般には $\mathrm{Nu} / \mathrm{Pr}^{0.4}$ 〜Re $e^{0.8}$ で与えられる.四 5 中の高レイノルズ数域に対 寸る直線は $N u / \mathrm{Pr}^{0.4} \sim[R e(d / L)]^{0.8}$ をシミュレーシ ヨン結果にフィッティングしたもので，次式で表され る.

$$
N u=0.15 \operatorname{Pr}^{0.4}[\operatorname{Re}(d / L)]^{0.8}
$$

シミュレーション結果は煟流解であるが, 周波数が高 い場命には境界筧付近での熱搪散が活発で，結果的に 乱流場と阔様な $\mathrm{Pr}$ や Reに対する依存性在示与こと になる。

\section{4. 自然対流が作用する場合の熱流動特性}

$4 \cdot 1$ 速度分布と温度分布 周波数が低いときに は振動によって誘起される速度が小きく，重力が作朋 する場では自然対流の效果によって流速行布と温度行 布が大きく影響される。そこで低周波数域です断面内 速度行布 上温度分布の一祘期にもたる変動について説

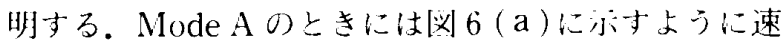
度分有は壁付近では俱の側に，バルク部分ではょた側 にかたよっている。これは上端の留温泩体が側隼で泠 却され，それによって側壁近浐に下降流が、そしてバ ルク部行には上㤠流が存在することを意味する。一ま

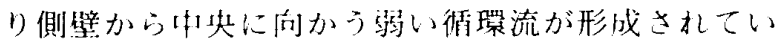

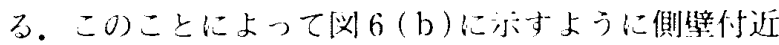

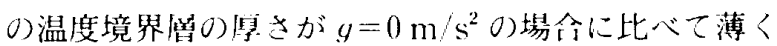

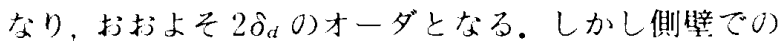
温度こう配はレイノルズ数が非常に低い場命を除いて

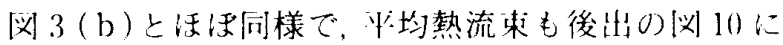
示寸ように $g=0$ に対する絬果とほ任一致する。また

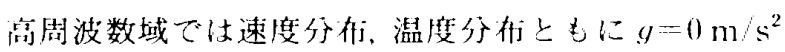

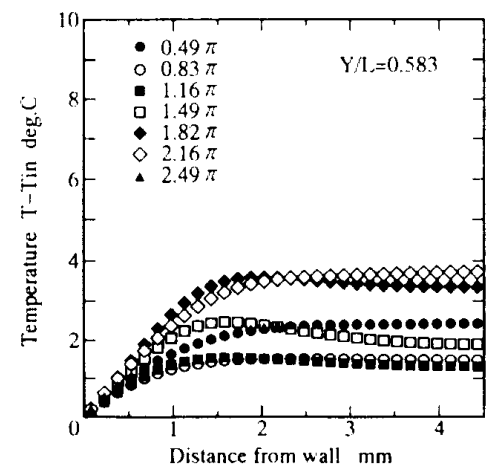

(b) Temperature distribution

Fig. 6 1)istribution of velocity and temperature $\left[g=-9.8 \mathrm{~m} / \mathrm{s}^{2}, j=0.3 \mathrm{H} z, \Delta L=3.0 \mathrm{~mm}\right.$. Mode A, see legend in (b) $]$

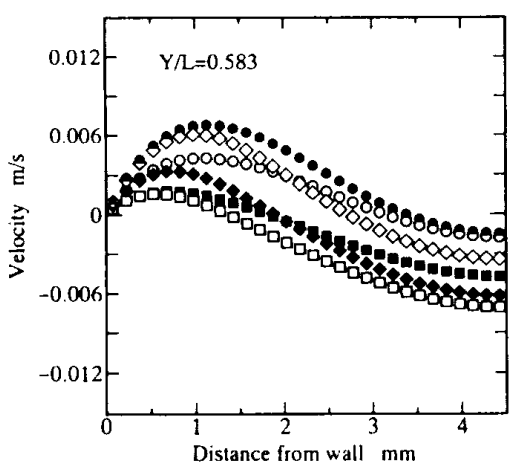

(a) Velocity distribution

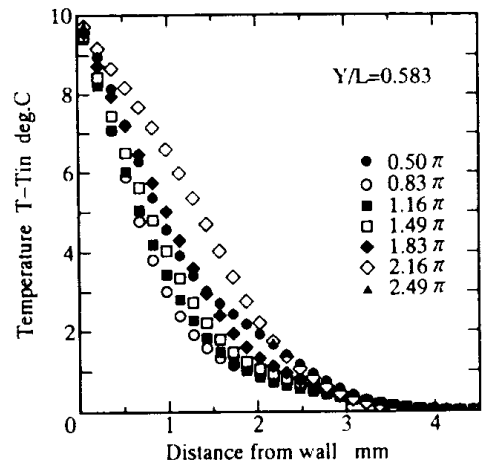

(b) Temperature distribution

Fig. 7 Distribution of velocity and temperature $\left[g=-9.8 \mathrm{~m} / \mathrm{s}^{2}, f=0.3 \mathrm{~Hz}, \Delta L=3.0 \mathrm{~mm}\right.$, Mode $\mathrm{B}$, see legend in $\left.(\mathrm{b})\right]$ 


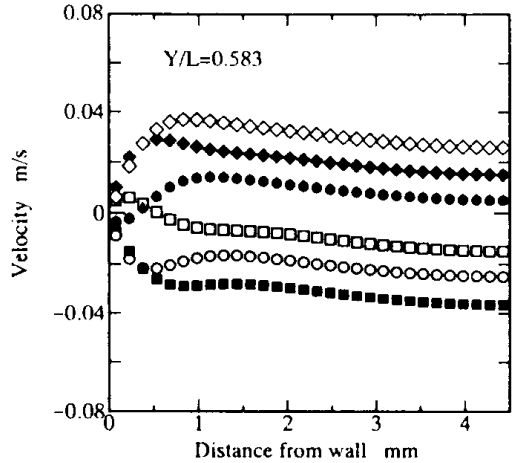

(a) Velocity distribution

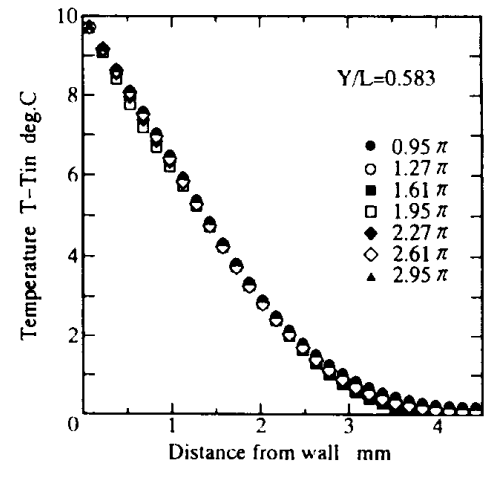

(b) Temperature distribution

Fig. 8 I Distribution of velocity and temperature

$\left[y=9.8 \mathrm{~m} / \mathrm{s}^{2}, f=3.0 \mathrm{~Hz}, \Delta L=3.0 \mathrm{~mm}\right.$, Wode $\mathrm{B}$, see legend in $\left.(\mathrm{b})\right]$

0場命とほとんど-一致する。

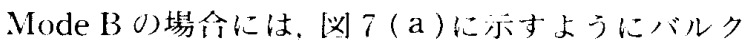
部分を卜降し，側壁付近を上最する衡環が明りょうに 諗められる。温度分布はバルク部少ではほとんど変動 せず，境界檿部分でのみ大きく変動する。側壁での温 度こう配は $g=0 \mathrm{~m} / \mathrm{s}^{2}$ に対するよりも大きく，当然熱 流束も大きい。こ0場会忙目然対流が熱輸送に大きく 影然している。张動周波数が增加与ると振動によって 誘起される流れが相対的に大きくなり， $f=3 \mathrm{~Hz}$ 程度 になると戍8（（）に示すようにバルク部尔から側壁方

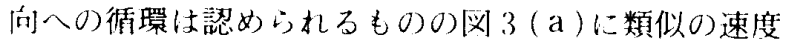
你仴となる。しかし温度分㟈は一周期の間でほとんど 変動しない。このことは倣動境界膚を介しての低温端 八の熱輸送が效果的に行われないことを意味し、その ために側壁での温度こう配も小さくなっていると考え られる。これに刘伈して側壁での半均熱流束毛闵 100 $R c^{\prime}=100$ 200で極小檤となっている(記光は咸 11 と 共通). $\Delta L=3 \mathrm{~mm}$ の場令には $f=6.62 \mathrm{~Hz}$ 付近で再び 温度変動が諗められるようになり，振動による強制対 流的な熱輸送が支配する状態に遷移与る。 $f=10 \mathrm{H} z$ 程 度では速度分布には自然対流の影箱がほ上んど虫めら れず，また鼬度分布も洞 9 に示すように基本的には $g$ $=0 \mathrm{~m} / \mathrm{s}^{2}$ 0)場合と间样であるが，バルク部分で変動带 域がより黍温側にある。このことは境界層に相対的に バルク部尔の温度が高いことから，浮力の作用によっ て高温部分が $g=0 \mathrm{~m} / \mathrm{s}^{2}$ の場合よりもさらに上打に抬 大したためであろう。しかし壁面での温度こう配は $g$ $=0 \mathrm{~m} / \mathrm{s}^{2} 0$ 場令とほとんど変わらない。

$4 \cdot 2$ 側壁での熱伝達特性自然対流効果が影響 する場合についても3・2節と问様に NuRe関係を求 め，そのうち水に対する結果が䦌11に六されている。

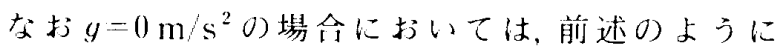

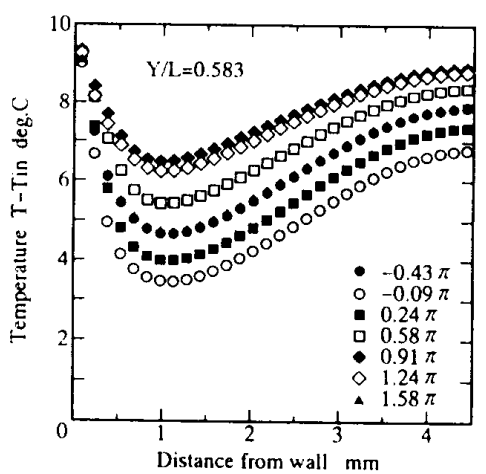

Fig. 9 Temperature distribution $\left(g=-9.8 \mathrm{~m} / \mathrm{s}^{2}\right.$, $f=10.0 \mathrm{~Hz}, \Delta L=3.0 \mathrm{~mm}$, Mode B)

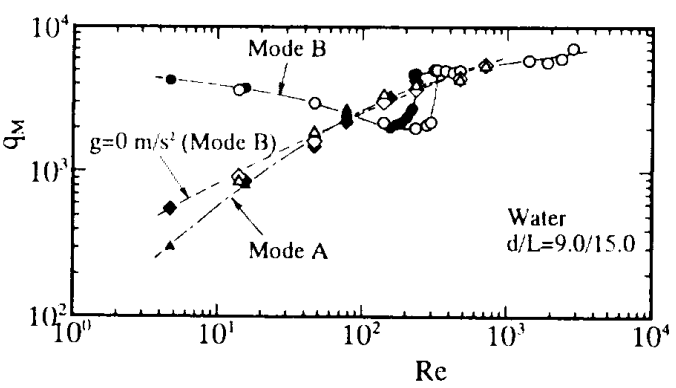

Fig. 10 Average heat flux at the wall (See legend in Fig. 11)

Mode Aに対する結果と Mode Bに対する結果が一 致しているので, ここでは Mode Bの結果を代表とし て示している．Mode A の場合にはNuの值は低レイ ノルズ数域においては $g=0 \mathrm{~m} / \mathrm{s}^{2}$ の場合よりも大きい が、レイノルズ数の増加とともに，緩やかに堌加して $R e=200$ 付近で $g=0 \mathrm{~m} / \mathrm{s}^{2}$ の場合の特性に漸近する。 网 10 では熱流束は低周波数域で $g=0 \mathrm{~m} / \mathrm{s}^{2}$ の場合よ りも小さく, 一方ヌッセルト数は逆に $g=0 \mathrm{~m} / \mathrm{s}^{2}$ のそ れよりも大きくなってるのは主として対数斗均温度 差の挙動による.つまり Mode A では低周波数域でバ 
ルク部分をト帠する循環流が存在し，低温側の流体が 押しトげられ，洞 3（b)，6（b)を比較して明らかな ように温度差が小さくなっていることによる。また Nu-Re 関係に振幅 $\Delta L$ の影響はほとんど認められな い.

Mode B に対する結果ではレイノルズ数が非常に小 さい領域では Mode A と间程度のNu做となってい るが、レイノルズ数の增加とともにまず減少して極小 值を车ち，その後急激に上昇する. $g=0 \mathrm{~m} / \mathrm{s}^{2}$ の場命の 結果と比較すると、特に $R e=30$ 以下゙では $g=-9.8$ $\mathrm{m} / \mathrm{s}^{2}$ に対する結果のほうが $\mathrm{Nu}$ 值は大きくなってい る.このような低レイノルズ数域では振動による強制 対流熱伝達よりも自然刘流熱伝達のほうが大きく，振 動を加えることによって逆に熱伀達を阻售しているこ とになる，Re=30から $200 \sim 3000$ 領域では $g=0 \mathrm{~m} /$ $\mathrm{s}^{2}$ の場合よりも $N u$ 傎はかなり小さくなっている。

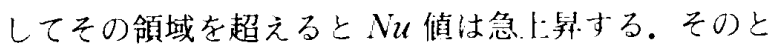
きのレイノルズ数は振幅が小さいと若けではあるが低 いレイノルズ数で遙移する。高周波数域ではバルク部 分は熱移動に大きく笴与せず，壁付近の流れい举動が 支配肉子よなって艮 10 に示すように熱流束は $g=0$ $\mathrm{m} / \mathrm{s}^{2}$ の場命とほとんど変わらないが，バルク部行の 温度が相対的に高く，側壁との温度差が小さくなって いるため $N u の$ 值としては $g=0 \mathrm{~m} / \mathrm{s}^{2} の$ 場命よりも大 きくなっている。

Churchill ${ }^{199}$ は共存刘流場でのヌッセルト数 Nu在 強制対流場でのヌッセルト数 $N u F$ で周規化し，Nu $N u_{F}$ を自然対流熱伝達によるヌッセルト数NuNと $N u_{F}$ の比 $N u_{N} / N u_{F}$ に対して相関を求めた。 NuN $N u_{F}$ はプラントル数に対する依存性在除けば基本的 にはグラスホフ数 $G r$ とレイノルズ数の関数である。 そこでレイノルズ数としてはd/Lで補林した Re $(d /)$ L)を用い，また強制対流熱伝達特性 $N u_{F}$ としては $g$

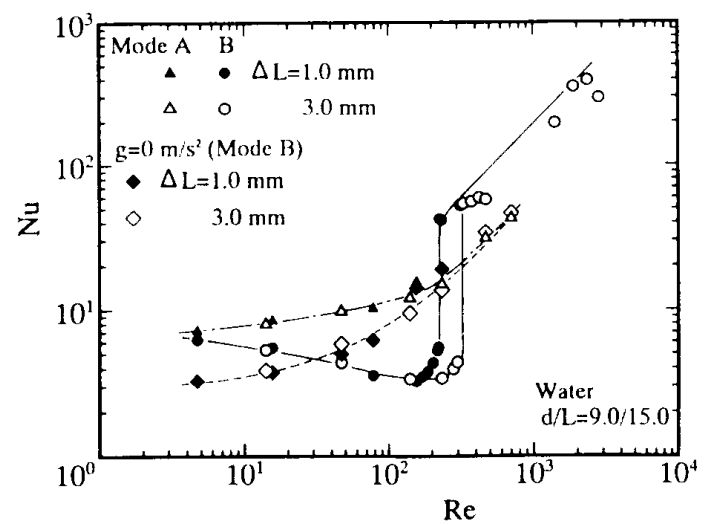

Fig. 11 Heat transfer at the wall $\left(q=-9.8 \mathrm{~m} / \mathrm{s}^{2}\right)$
$=0 \mathrm{~m} / \mathrm{s}$ の商周波数域での相関式 $(3)$ 者朋いて，Nu $N u_{F}$ と $(r / R e(d / L)$ O)関係が咸 12 にふするれている。 ここで（rをを算出する際の代表温度差には簡単のため $\left|T_{w}-T_{\ell}\right|(=10 \mathrm{~K})$ ，代表埌きは流路幅 $d(=9 \mathrm{~mm})$ を 用いた。

Mode A の場合には（）/Re(d/L)が小さい，つ来 りレイノルズ数が大きい領域では Nu/NuF〜1とな

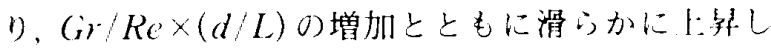
ていく.一方, Mode B O場命には Gr/Re $(d / L)$ が小 さい場合には Nu/NuF は 3 程度と比較的大きな俌で あるがレイノルズ数の增加とともに( $\mathrm{h}(\mathrm{R}(\mathrm{d} / \mathrm{L})$ ～ $10^{2}$ 付近で大きく隇少して極小储をもち。に

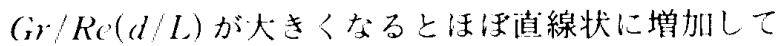
Mode A のシミュレーション結果に漸近する。 Chur chil らの結果との対比から Mode A は強制対流熱位 達に自然刘流効集がアシストする場合であり，Mode B は自然対流效果が強制刘流效果と対抗する場合に対 伈していることになり，通常の共存対流現象と间様の 伝熱機構が往復振動系に扔いても認められることが甘 かる。

$4 \cdot 3$ フローパターンの分岐現象 Mode B 0)条

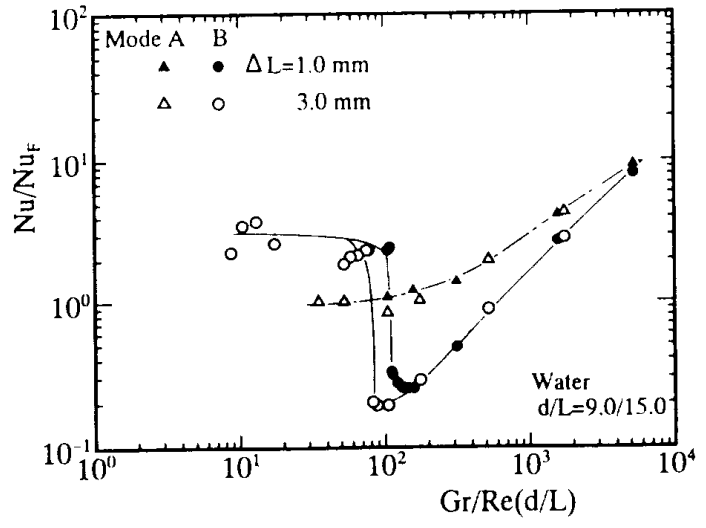

Fig. 12 Mixed canvection heat transfer

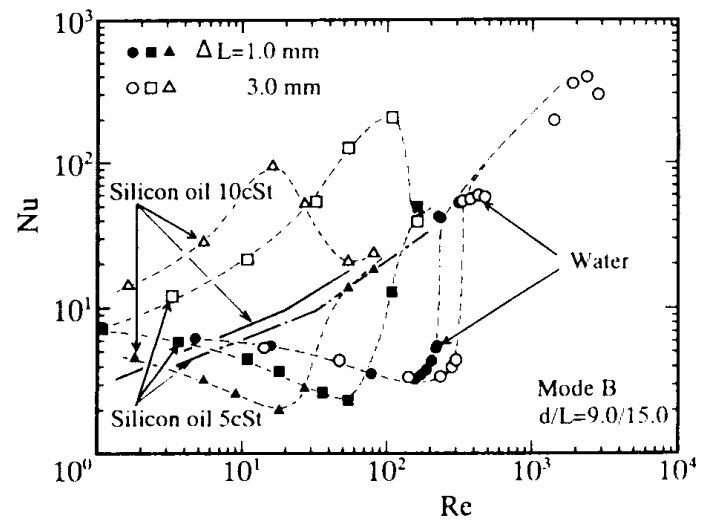

Fig. 13 Bifurcation of mixed convection heat transfer 


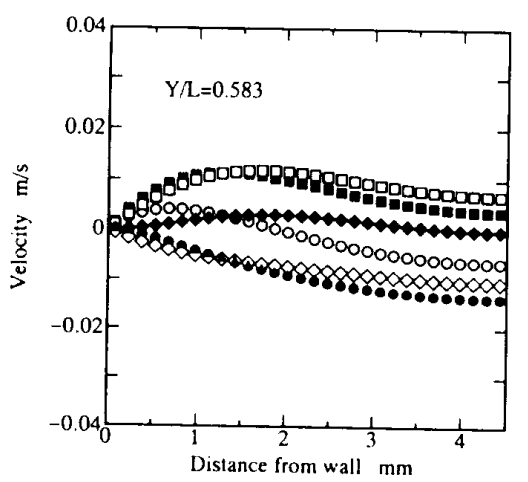

(a) Velocity distribution

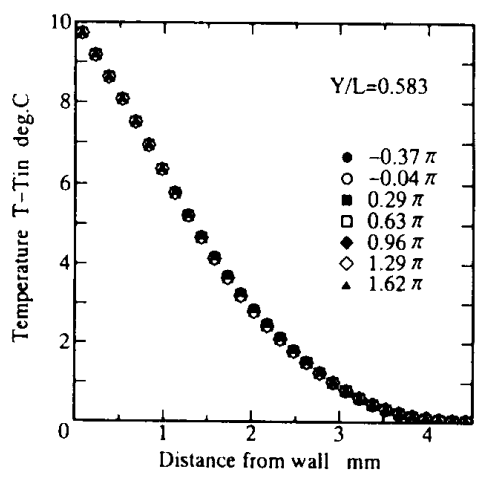

(b) Temperature distribution

Fig. 14 Distribution of velocity and tempercture

[Silicon oil $10 \mathrm{cSt}, g=-9.8 \mathrm{~m} / \mathrm{s}^{2}, f=3.0 \mathrm{~Hz}, \Delta L=1.0 \mathrm{~mm}$, Mode B, see legend in (b)]

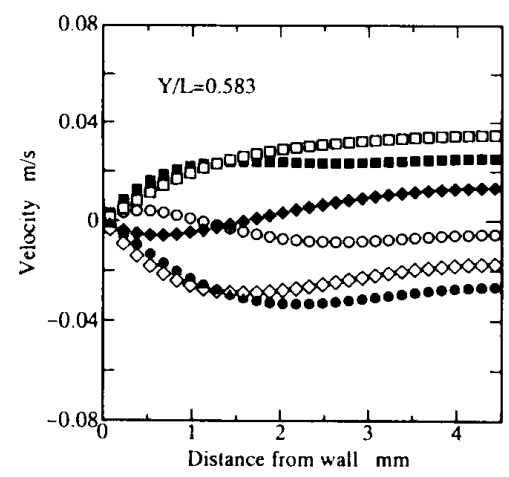

(a) Velocity distribution

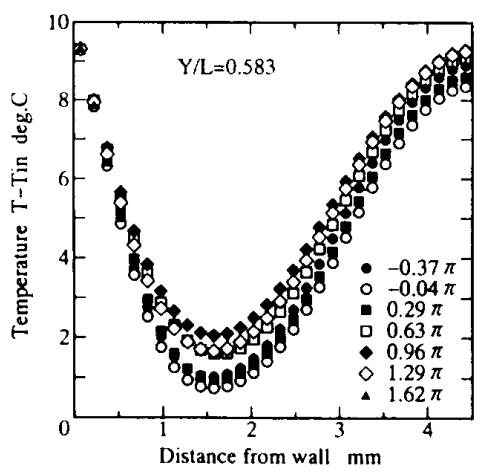

(b) Temperature distribution

Fig. 15 Distribution of velocity and temperature

[Silicon oil 10 c.it, $g=-9.8 \mathrm{~m} / \mathrm{s}^{2}, f=3.0 \mathrm{~Hz}, \Delta L=3.0 \mathrm{~mm}$, Mode B, see legend in (b)]

件のもとで作業流体にシリコンオイルを用いた場命の $N u R e$ 関係が水に対するシミュレーション結果とと もに汹 13 に永されている。拢幅 $\Delta I=1 \mathrm{~mm}$ の場命に はNuは水の場合と问様にRe O增加とともに減少し て極小傎に達した後，Re〜60(5 cSt)，30(10 cSt) 付近

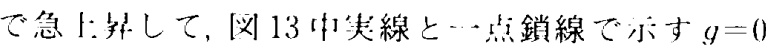
$\mathrm{m} / \mathrm{s}^{2}$ りをの強制刘流的な熱位達特性に近づくのに 対して，振幅が $\Delta L=3 \mathrm{~mm}$ では椆波数ひ堌大ととも にNu储はまずト昇して極大值をもち，その後隇少し て強制刘流的な特性に溸近寸るというまつたく逆の特 性をふホすこになる。四 14,15に $f=3 \mathrm{~Hz}$ で，振幅が $1 \mathrm{~mm}$ と $3 \mathrm{~mm}$ の場命の流速分布，温度分布去して いる. $\Delta L=1 \mathrm{~mm} 0$ 場命には水の場令と闹様にバルク 部分ではトト降流が存在し，側壁付近でた算する循環が 形成されている。このとき温度変動はほとんどなく， 側壁での熱流束も小さく，そして振動による熱輸送も 良好ではない, $\Delta L=3 \mathrm{~mm}$ の場合には Mode A の場合 と同様に側壁付近で下降，中央部分でた帠という循環 が存在する。このため側壁付近での温度こう配が大き
く，熱流束も大きくなり，したがってNuも大きい值 となる。しかしこのような循環も周波数が㤋大きい 場合には振動によって誘起される流れが支配的となっ て $g=0 \mathrm{~m} / \mathrm{s}^{2}$ の場合と同様の速度行有，温度分布とな る。このように振幅によってフローバターンが分岐す る機構は以ドのように考えられる。ここで行った数值 シミュレーションに扔いては初期条件として流路内の 流体は一様に低温側の温度に等しく静止している。 Mode Bでは側壁上卜端温度が初期流体温度よりも高 く，したがって振動を印加しなければ壁面上舁，中央 下降の循環が必然的に形成される。振幅が小さい場合 にはこの循噮を大きく変化させる程度の速度外乱を与 えることにはならないが，振幅が大きい場合には自然 㕵環に比して大きな速度外乱が加振開始とともに流路 上向きに与えられ，しかも流路中央では速度が大きい ことから戍 15(b)のように図14(b)とは逆の循環が 形成される。実現象においても加振方法のいかんによ ってはこのようなフローパターンの分岐が発生するこ とが予想される。水り場命には例えば振幅を $5 \mathrm{~mm}$ 程 
度にまで大きくしてもこのような分吱は認められなか った。このことは水のほうがシリコンオイルに比べて 粘度が小さく，同じ温度差に対しても自然対流によっ て誘起される循環流れが強いからであろう。

\section{5. 結}

ドリームパイプの熱交換器部分に着目して往復振動 場での熱伝達特性に関する数值シミュレーションを行 い，基本的な熱伝達特性を明らかにするとともに，重 力の作用によって共存対流現象が認められることが明 らかとなった。ここで得られた結果は計算機容量など の制約から主として幾何学的に狭い範囲に限られてい るが，定性的にはスケールにかかからず発現する現象 と考えられる、今後実験的および理論的な検証をすす めるとともにさらに広範囲のシミュレーションを行う 必要があろう。

\section{文献}

(1) Kurzweg, U. H. and Zhao, L., Phys. Fluids, 2711 (1984), 26242627.

(2) Kurzweg, L.H., Trans. ASME, J. Heat Transf., 107 $(1985), 459462$
（3）小澤守・坂[1恕司・洪(1八朗・河本明，市居时彦・小野茂 樹. 機論, 56 530. B (199(1), 3056 3063.

(4) Ozawa, M. and Kawamoto, A., Int. J. He'at Mass Transf .. 34 12(1991), $3083 \cdot 309.5$.

（5）西尾茂文・本間淦・張暐民機論，60569，B(1994)，233 239

（6）西尾茂文・張暐比，機論，60570，B(1994)，627633.

（7）西尾茂文・史小丢・舟津功治，機論，60-578，B(1994)， 3498-3503.

（8）富永昭，低温．学，25 5(1990)，300 303.

（9）勝付正文, ヒートハイイ゚技術，123(1993)，1227

（10）稃葉武彦、機論, $60575 ， B(1994)$. $2538 \cdot 2543$.

(11）高橋一郎。機論, 61 581，B(1995)，275 282.

(12) Watson, E. J., J. Fluid Mech., 133(1983), 233244.

(13) Kim, S. Y., Hyun, J. M. and Kang, B. H., Proc 2nd JSME KSME Thermal Eng. Conf., (1992), 4146.

(14) Chung. J. H. and Hyun, J. M.. Int. J. Heat Mass Tran. sf.. 37 1(1994). 4352.

(15) Kikuchi, Y., Ohno. Y. and Takahashi, M., Heat Transf., 5 (1994), 495500

(16) Kaviany, M., Trans. ASME, J. Heat Transf. 112(1990), 4955.

(17) Kaviany, M. and Reckker, M., Trans. ASME, J. Heat Transf., 112(1990), 5663.

(18) Schlichting. H., Boundarey Laver Theory, 6th ed. (1968), 8587 . McGraw Hill, N.Y.

(19) Churchill, W., Heat Fxchanger Design Hemdhosk. 2. C.2.5.9(1983) 1 7. Hemisphere P'ub. Co.. N. Y. 